\title{
POSITION OF COMMUNICATION IN MEDICAL EDUCATION: A STUDY ON CURRICULUMS OF MEDICAL FACULTIES IN TURKEY ${ }^{1}$
}

\section{Tıp Eğitiminde Iletişimin Konumu: Türkiye'deki Tıp Fakültelerinin Müfredatları Üzerine Bir inceleme}

\author{
Doç. Dr. Hatun BOZTEPE TAŞKIRAN²
}

Istanbul University, Faculty of Communication

0000-0002-3447-9174

\begin{abstract}
Health communication is a discipline with the purpose of raising individual and public awareness about diseases and preventive measures, consisting of communication strategies and practices that focus on the protection and improvement of health as well as gaining health back. In spite of the widening scope of health communication, what is emphasized is the micro-level of the area with the traditional perspective, and communication between providers of health care service and patients has been observed to have primary significance. In the literature, it has been acknowledged that communication education should be added to the curriculums of medical schools due to the contribution successful management of doctor-patient communication could make to the achievement of desired results in health care service. This study, done in line with the aforementioned agreement in the literature, has been designed to learn whether 104 Turkish medical faculties, which provide undergraduate medical education, has added any theoretical courses or education centered on communication skills to their curriculum, and to determine how they construct their courses and education aimed at improving communication skills. The findings of the research have shown that the majority of the faculties has theoretical communication education in their curriculums. It has been seen that some faculties offer theoretical communication education as a separate course in their curriculums while some others integrate it into other courses as a topic.
\end{abstract}

Key Words: Health Communication, Medical Faculties, Medical Education, Curriculums, Turkey

Öz: Sağlık iletişimi hastalıklar ile koruyucu tedbirler açısından bireysel ve toplumsal açıdan farkındalık ve bilinç oluşturma amacına sahip, sağlığın korunmasına ve geliştirilmesine, sağlığın kazanılmasına odaklı iletişim strateji ve uygulamalarını kapsayan bir disiplindir. Sağlık iletişiminin gelişen kapsamına rağmen, alanın geleneksel bakış açısıyla mikro seviyesine odaklanıldığı, sağIık hizmetlerini sunan kişilerle hastalar arasındaki iletişimin ön plana çıktğı görülmektedir. Literatürde sağlık iletişimde hekim ile hasta iletişiminin başarılı biçimde yürütülmesi için tıp müfredatlarında iletişim eğitimine yer verilmesi yönünde bir kabul bulunmaktadır. Literatürdeki kabul doğrultusunda bu çalışmada Türkiye'de lisans düzeyde tıp eğitimi veren 104 tip fakültesinin müfredatlarına iletişim becerilerine yönelik teorik bir ders, eğitim ekleyip eklemediklerini, iletişim becerilerini geliştirmeye yönelik derslerini ve eğitimlerini nasıl yapılandırdıklarını tespit etmek üzere planlanmıştır. Bulgular lisans düzeyinde tıp eğitimi veren fakültelerden çoğunluğunun teorik iletişim eğitimine müfredatlarında yer verdiğine işaret etmiştir. Bazı fakülteler teorik

\footnotetext{
${ }^{1}$ Makalenin Türü: Araştırma Makalesi

${ }^{2}$ e-mail: hatun.boztepe@istanbul.edu.tr
} 
iletişim eğitimini müfredatta ders olarak konumlandırırken, bazı fakültelerin teorik iletişim eğitimini diğer derslerin içerisinde konu olarak konumlandırdığı tespit edilmiştir.

Anahtar Kelimeler: Sağlık iletişimi, Tıp Fakülteleri, Tıp Eğitimi, Müfredatlar, Türkiye

\section{INTRODUCTION}

Health communication, which aims at raising individual and public awareness about diseases and preventive measures and improving health methods so as to help people and communities acquire ideal behavior patterns about health, is a discipline that has become more important in recent years. It is also about managing all communication process about health effectively and successfully. On the one hand, health communication informs individuals and society about issues that pose risk for health, on the other hand, it focuses on helping them acquire ideal attitudes and notions about health. Thus, it works for sustainment of health, eliminating conditions that threaten health, and gaining health back.

When evaluated in light of the aforementioned aspects, it has been seen that health communication could have crucial functions both for individuals and societies. At the micro-level, the discipline with its aspect of interpersonal communication makes it possible to maintain productively and successfully not only the communication process between patients and health care workers but also the communication among themselves. In addition, at the macro-level, the field with its feature of mass communication management process contributes to the circulation of information about health, raising awareness about health risks and promoting social consciousness about health.

The academics working on the field are interested in the ways health communication could happen as part of interpersonal communication, focusing, in particular, on the management of the communication process between patients, doctors and other health care workers, and the communication solely among health workers at the micro-level. Health communication studies on the issue investigate the effect of communication on gaining health back, adopting ideal behavior patterns and belief about health, making a correct diagnosis and choosing an appropriate treatment method, sustaining doctor-patient collaboration in the treatment process, using time both effectively and productively, and yielding patient satisfaction. The researches at the macro-level focus on raising awareness about health risks through mass communication, improving social consciousness, making information about health available to wide target audiences fast. Macro-level researches also focus on designing and performing health communication campaigns on various topics, and thus, improving health in general.

In spite of the widening scope of health communication, it has been observed that the discipline traditionally pays attention to doctor-patient communication in the level of interpersonal communication. To fulfill its promises for interpersonal communication, it is significant for the field to teach health care staff basic communication skills. By taking the information mentioned above as a starting point, this study deals with the field in terms of interpersonal communication at the micro-level and investigates whether the undergraduate curriculums of Turkish medical faculties have theoretical courses and communication education that teach their students basic communication skills. The findings were obtained through the content analysis technique which is included in the qualitative research methods.

\section{Concept and Scope of Health Communication}

As a discipline developed to highlight the multiple roles communication plays in health care service and development of health (Kreps, Bonaguro \& Query, 1998: 2), health communication focuses on people's living well, protecting their health and gaining their health back, and explores the effects and contributions communication 
has in achieving these goals. Health communication encompasses all types of communication that are realized through contents on health, contributing significantly to the improvement of health. It also makes possible to get access to correct information on health for individuals and societies, raise awareness on health risks and adopt ideal behavior patterns for health. Health communication is an area in which communication strategies are used with the purpose of informing individuals and society to improve health and affect their decisions (Edgerton, 2009: 375), health communication warns both individuals and the public about diseases, talks about preventive measures, and contributes to raising awareness about health risks and managing patient and health care staff communication effectively and successfully.

According to McKeever (2014: 1410), who defined health communication "as it has been described by the Centers for Disease Control and Prevention (CDC), the National Cancer Institute, and US Department of Health and Human Services, it is "the study and use of communication strategies to inform and influence individual and community decisions that enhance health." When considered from this point of view, health communication emerges both as an important academic subject of research and a discipline that brings out significant effects in practice.

The recognition of the fact that effective communication has a central role in the emergence of effective health care service (Berry, 2007: 3) makes the importance of communication for health more concrete. Broad and advancing aspects of health communication studies strongly draw attention to the centrality of the communication process in health care services (Kreps, 2012: 12). These perspectives point out to the key role health communication plays in the distribution and improvement of health.

Health communication, which has important features for individuals and society, could be defined as human interaction on health care services (Kreps \& Thorton, 1992: 120). The discipline, which might also be described as a form of communication individuals or groups carry out according to their target groups (Okay, 2012: 11), encompasses every type of interaction about health in the level of interpersonal communication or mass communication.

Ratzan et al. (1994: 361) states that health communication is considered an art and a technique that informs, affects and motivates individuals and societies about significant issues concerning health. It is said the content of health communication includes policies about the prevention of diseases and improving and protecting health as well as improving living standards and health of individuals in societies.

Emerged in line with the relationship between the areas of communication and health, health communication is noteworthy as a significant part of the studies carried out to improve individual and public health. The discipline, which contributes to the purposes of prevention of diseases and improvement of health, consists of health care professional-patient relations, communication among health care staff (or interpersonal communication in health care service), individuals' search for knowledge about health and use of it, people's performing clinical advises, forming messages about public health, dissemination of information on individual and public health risks (risk communication), dissemination of health messages as part of mass communication, education on how consumers and providers of the health care service reach to systems on public health and protection of health, and novelties that started to be used in health care area as a result of the developments in communication technologies such as telehealth, interactive health and telemedicine (Çınarlı, 2008: $43-44)$. With its wide scope, it is important that health communication contributes greatly to the purposes of protection and improvement of individual and public health. 
As stated by Schiavo (2007: 7), health communication is a multidimensional and multidisciplinary approach that aims at affecting individuals, societies, health care professionals, private groups, policymakers and the public in general through sharing and communicating knowledge about health to different target masses with the purpose of supporting, revealing, adopting or sustaining policies, practices or behaviors that improve outputs of health.

Health communication contributes to the prevention of diseases, improvement of health, doctor-patient relationships, designing health communication campaigns, the announcement of health risks through mass media and creating changes about individual and social attitudes concerning health. For individuals, it helps create awareness about health risks and diminish them. For society, health communication strategies could affect public agenda, resulting in gathering support for policies and programs, positive changes about attitudes, and improvement of healthy behaviors, belief, values and social norms that could affect living standards in general (Rosiek-Kryszewska et al., 2016: 19).

For health communication to continue its functions for individuals and public, mass communication, which makes it possible to disseminate knowledge about health to wide audiences, and interpersonal communication between patients and health care professionals are important. According to Yilmaz (2013: 97), who states that strategies used in health communication could be investigated as part of mass communication and interpersonal communication, health communication includes correct dissemination of knowledge about health, and telling society about the benefits of adopting healthy behavior patterns and the effects of diseases and unhealthy behaviors, how individuals could access to health care services and correct diagnosis and treatment units, and the realization of effective communication between patients and health care professionals, as well as doctor-patient collaboration during the treatment process.

Health communication practices, which point out to national and global health issues, and campaigns to improve individual and public health plans in the mass communication level (Shin et al., 2011: 27), focus on the communication process between health care professionals and patients in the interpersonal level. Hamel (2010, p. 100) states that in spite of the developing nature of health communication, what is focused on is the micro level of health communication, that is the communication between professionals who provide health care service and their patients, with the traditional point of view. Similarly, Dutta (2009: 60 - 61) also notes that in health communication studies interpersonal communication is typically emphasized at the micro-level and communication between patients and doctors have prominence. According to him, researchers who focus on this aspect of health communication, are interested in describing and explaining the nature of doctor-patient relationships and features of health communication skills, and thus, designing programs oriented at forming skills for doctors and patients.

As said by Kreps, Bonaguro and Query (1998: 1), providers and consumers of health care service use their skills to access information about health, forming knowledge and transfer it, and thus, it becomes possible to make important decisions for treatment, and adapt to changing conditions of health and activities for the prevention of diseases. In line with this perspective, it could be said that doctors, as one of the two parties of health communication who provide health care services, need communication to form knowledge about health and disseminate it while patients need communication to acquire correct knowledge about health and adopt activities that prevent diseases.

As indicated by Koçak and Bulduklu (2010: 8), who noted that health communication could happen in various ways such as doctor-patient communication, group communication, and mass communication, a patient's 
listening to his/her doctor's advice carefully while receiving health care service, a doctor's explaining details of his/her patient's problems in detail, carrying out treatment process collaboratively, and the emergence of trust between doctor and patient is related to the doctor-patient communication aspect of health communication. To manage that aspect of the discipline successfully, it is a must to improve communication capability and skills of doctors, who are among providers of health care service. Health communication researchers, on the other hand, play an important role in the improvement of these capabilities and skills.

Doctor-patient communication comes first in the areas communication researchers contribute to by carrying out studies in the field of health care service process, and the studies in the area inspect communication strategies and messages used by doctors and patients in medical appointments (Dutta, 2009: 64). As stated by Kreps (2012) health communication researchers contribute to affecting behaviors of health care providers and practitioners who work for the improvement of health, and help them reach important health purposes such as acting as guides in decisions concerning health. In addition, by creating awareness on issues about basic communication, health communication could help the improvement of relationships between health care providers and doctors, and achieving desired health outcomes successfully. Communication methodology and education on how to create messages could make health care providers shape their communication skills and address questions and anxiety of patients more effectively (Schiavo, 2007: 114).

\section{Position of Communication in Medical Education}

Of the most primary purposes of health care service are protecting, improving and gaining back health. Communication has a central role in achieving these goals successfully. Since the existence of effective and productive communication process in the interpersonal level contributes to getting desired results in health care services. Making correct diagnoses, providing the right treatment, achieving patient satisfaction and doctor- patient cooperation is also be possible with the successful management of doctor-patient communication.

It is accepted that employees are desired to have a high level of communication skills in job categories in need of deep interpersonal relations such as education, tourism, banking and health (irak et al., 2017: 198). In turn, the need for doctors, who are the firsthand providers of health care service, to receive education on communication skills is a current topic of discussion concerning doctor-patient relationships for which interpersonal relationship has vital importance.

That the quality of communication between doctors and their patients is a significant aspect of health care (Dalen, 2013: 294) points out to the necessity of providing doctors with communication competence and skills in addition to medical knowledge during their education process.

According to Deveugele (2015: 1287) communication has a central role in all interpersonal encounters in health care, and as the studies on the issue have also indicated "effective communication is connected with satisfaction, compliance and to some extent with medical outcomes." For this reason, the need to teach both medical students and professionals how to communicate with their colleagues and patients has been widely acknowledged.

As Bachman et al. stated (2013: 24) effective communication should be one of the main purposes of health care education/training. Communicating with patients, their relatives and colleagues effectively needs to be one of the core skills all health professionals must have. Therefore, basic communication skills should be taught to all health professionals including nurses, pharmacists, dentists, doctors or other experts during their academic education. 
Since health care professionals, as a requirement of their jobs, always have to communicate with patients, and their acquaintances/relatives from a variety of socio-cultural backgrounds, communication education is fundamental in health care service. Managing communication process successfully both as a doctor and a patient affects treatment procedure, resulting in patient satisfaction and professional satisfaction for health care providers, and contributes to the image and reputation/dignity of health care institutions/organizations. A proper management of health communication is important for the mentioned reasons (Solmaz \& Duğan, 2018: 185). It must be realized that communication is a basic clinical competency that serves for ultimate patient satisfaction, makes the adaptation of patients to the advised treatment and health habits easier and helps effective use of time. Understanding patients' cultural values, language preferences, differences, and the meanings they attach to verbal and nonverbal expressions is also necessary for the construction of satisfactory communication (Schiavo, 2007: 107). As communication success is also based on doctors' and other health professionals' understanding what patients think, and patients' correct appreciation of what health care providers tell (Başol, 2018: 3), it is important to add theoretical and practical courses that teach prospective medical professionals communication skills during their education in their curriculum.

Since it has been realized that effective communication between doctors, patients and their families is a must for the quality of health care service, the curriculums of medical education programs have started to be revised in order to teach health communication skills most effectively. Thus, through education, young professionals of health care have been prepared for the difficult task of helping patients (Street \& Haes, 2013: 27), which means fulfilling a basic purpose of health care service. As pointed out by Campbell et. al (2013: 543) "health professional education includes interpersonal communication and skill development." Due to the fact that the role communication has in health care service has been acknowledged, lots of medical schools and institutions that provide health care education from around the world have reconstructed their curriculums to offer courses on communication skills and thus, they have begun to carry out concentrated studies to improve the communication skills of health professionals and doctor-patient relationships (Akyurt, 2009: 19). In parallel to this tendency in worldwide, "medical schools in German speaking countries have just started to integrate these competencies in the regular curriculum" (Kiessling et al., 2010: 259). When the findings of a research by Xie et al. (2013: 827) in which they pointed out to the need for communication skill training for most nursing school students have been taken into consideration, it could be said it is also necessary to add communication skills courses to the curriculums of institutions that educate other health professionals.

According to the data above, it could be concluded that there is an agreement and acknowledgment that theoretical courses and education that aim at building and improving communication skills for prospective health care providers have to be added to the curriculums of health schools. Therefore, as Schiavo has implied (2007: $115)$, an ideal theoretical communication education designed for health care professionals should have the topics below:

- Communication methodologies and how they affect behavioral change

- How communication skills make effective use of time easy

- Benefits of effective communication

- Communication handicaps and how to address them

- Changing of patterns of belief and attitude on health depending on the varieties of culture, ethnicity, age, and sex

- Real-life examples

- Interactive learning methods/practices designed for prospective health professionals to test and (help them) perform their communication skills in different possible/potential scenarios 
It can be said that if theoretical communication education of prospective health care providers includes these topics health care services can be more effective.

\section{Method}

\subsection{Purpose of the Study}

One of the concerns of health communication in the interpersonal level is the communication process between doctors and their patients. If it is done successfully and effectively, it contributes greatly to the outcomes of gaining health back, adopting ideal health attitudes and belief, making a correct diagnosis and choosing the right way of treatment, doctor-patient collaboration during the treatment process, efficient and productive use of time, and patient satisfaction. Hence, in addition to equipping doctors with professional medical knowledge, their education should also support them with courses about the improvement of communication skills.

In line with the acknowledged need for the improvement of communication skills in health education, a research has been conducted as part of this study to discover whether Turkish medical higher education institutions have added any theoretical courses or education about communication skills to their curriculums, and how they constructed their courses and education aimed at developing communication skills.

With the findings of the study, the position of communication skills in Turkish medical education will be revealed. In compliance with these purposes, the research is expected to answer the questions below:

- Research Question 1: Have the curriculums of Turkish medical higher education institutions been constructed for the acquirement and improvement of communication skills?

- Research Question 2: What is the scope of the theoretical communication skills courses or education in Turkish medical higher education institutions?

\subsection{Limitations}

Although it is known that communication skills have a central role in the relationships between all health care providers and patients, the scope of this research has been limited to the Turkish medical schools that educate prospective doctors. Another limitation of the research is that it only aims at laying out the position of communication in the theoretical education of these schools.

\subsection{Population and Sample}

The population of the research is Turkish medical higher education institutions. As the curriculums of the entire institutions have been investigated, no sampling has been done.

\subsection{Research Technique}

Content analysis, a qualitative research method, has been decided to be used to obtain findings that will be able to answer the research questions. The curriculums of the Turkish faculties that provide medical education have been evaluated with content analysis between Oct. 1 and Nov. 12, 2019, presenting information about the position of communication in medical education in the country.

\subsection{Process}

The data gathered by evaluating the curriculum of Turkish medical faculties via content analysis have been processed by being codified into SPSS and assessed through a frequency analysis, a part of definitive statistics. 


\section{Results}

In Turkey, there are a total of 207 universities gathered under the roof of the Higher Education Institute (YÖK) (https://www.yok.gov.tr/universiteler/universitelerimiz, Access Date: 01.09.2019). Out of these, 129 are state universities (62.3\%), and the remaining $78(37.7 \%)$ are run by private efforts. There are a total of 104 medical faculties in Turkish state universities and foundation universities. Two hundred universities are active, others are passive, and a medical faculty in an active university has not accepted any students yet.

Among the 104 medical faculties, 61.4 percent $(n=64)$ offers communication education theoretically while 13.5 percent $(n=14)$ does not include any communication education in their curriculums. The curriculums of 26 faculties (25\%) have not been accessed. It is notable that theoretical communication education is given mainly in the freshman year $(n=57,27.3 \%)$. This is followed by the third year $(n=32,15.3 \%)$, the second year $(n=27,12.9 \%)$ and the fourth year $(n=3,1.4 \%)$, respectively. It has been observed that there is no theoretical communication education in the fifth and sixth years. It could be said theoretical communication education is intense in the first three years named pre-clinical period since the first half of the-six-year medical education focuses on theoretical education in general while the second half includes internships.

Out of the 64 medical schools that include communication education in their curriculums, 51 (79.7\%) position communication education as a theoretical course, and 13 do not have any theoretical courses on the topic (20.3\%). The number of faculties that integrate communication education into other courses as theoretical knowledge is 27 (42.2\%). It has been seen that some faculties have separate theoretical communication courses in their curriculum and they also offer communication education as part of other courses.

Interestingly, the theoretical courses that include communication education are named differently in the curriculums. When their distribution according to their titles is considered, it has been seen that "communication/communication skills" or "basic communication skills" comes first ( $n=18,28.1 \%)$. The table below shows the distribution of the theoretical communication courses in the undergraduate curriculum of the medical faculties according to their titles:

Table 1: Titles of Communication Courses in the Undergraduate Curriculums of the Medical Faculties

\begin{tabular}{|l|l|l|}
\hline Course title & Frequency & Percentage \\
\hline Communication/Communication Skills/Basic Communication Skills & 18 & 28.1 \\
\hline Behavioral Sciences Health Care Services/Communication in Health & 9 & 14.1 \\
\hline $\begin{array}{l}\text { Communication in } \\
\text { (Care)/Communication in Health Care Institutions }\end{array}$ & 10.9 \\
\hline Occupational Skills/Occupational Skill Practices & 4 & 6.2 \\
\hline Communication Skills in Medicine/Communication in Medical Education & 4 & 6.2 \\
\hline Clinical Communication Skills & 4 & 6.2 \\
\hline Roles of Doctors/Doctor Practices & 2 & 3.1 \\
\hline Introduction to Clinical Applications/Introduction to Clinical Environment & 2 & 3.1 \\
\hline Occupational Skills and Scientific Research Projects & 2 & 3.1 \\
\hline Occupational and Communication Skills & 2 & 3.1 \\
\hline Doctor-Patient Communication/Doctor-Patient Relationships & 2 & 3.1 \\
\hline Health Communication/ Health Communication and Health Education & 2 & 3.1 \\
\hline Ethics and Professionalism/Professionalism in Medicine & 2 & 3.1 \\
\hline Evidence-based Medicine/ Evidence-based Medicine Practices & 2 & 3.1 \\
\hline Human Relations in Medicine & 1 & 1.6 \\
\hline Behavioral Sciences and Communication Skills & 1 & 1.6 \\
\hline
\end{tabular}




\begin{tabular}{|l|l|l|}
\hline Health Communication with Hearing-impaired & 1 & 1.6 \\
\hline Stress, Stress Management and Interpersonal Communication & 1 & 1.6 \\
\hline Creative Drama & 1 & 1.6 \\
\hline Personal Branding Management Skills & 1 & 1.6 \\
\hline Representation of Medicine in Media & 1 & 1.6 \\
\hline Inter-occupational Communication & 1 & 1.6 \\
\hline Interpersonal Communication & 1 & 1.6 \\
\hline Positive Psychology and Communication Skills & 1 & 1.6 \\
\hline Social Sciences and Medicine & 1 & 1.6 \\
\hline Communication Seminar & 1 & 1.6 \\
\hline Effective Communication & 1 & 1.6 \\
\hline Doctorship and Society & 1 & 1.6 \\
\hline Effective and Good Talking & 1 & 1.6 \\
\hline
\end{tabular}

In forming the table, the fact that some faculties include more than one theoretical communication course in their curriculums has been considered.

It has been seen that the theoretical communication education in the medical faculty curriculums focuses on different topics. The most main topic title in communication education is patient-doctor communication $(n=38)$, and it is followed by education aimed at teaching doctors basic communication skills $(n=37)$. The table below shows the distribution of the theoretical communication education according to topic titles in the undergraduate curriculums of the medical faculties:

Table 2: Distribution of Communication Education According to Topic Titles in the Undergraduate Curriculums of the Medical Faculties

\begin{tabular}{|l|l|l|}
\hline Topic Title & Frequency & Percentage \\
\hline $\begin{array}{l}\text { Doctor-patient communication/Doctor- patient Relationship/ Doctor- } \\
\text { patient Meeting }\end{array}$ & 38 & 58.4 \\
\hline Basic Communication Skills & 37 & 57.8 \\
\hline Concept of Communication/Effective Communication & 28 & 43.8 \\
\hline Verbal and Non-verbal Communication/Body Language & 25 & 39.1 \\
\hline Communication with Acquaintances of Patients & 21 & 32.8 \\
\hline Empathy and Emphatic Communication & 20 & 31.2 \\
\hline Communication in Health Care Services & 18 & 28.1 \\
\hline Communication in Difficult-Bad Situations & 18 & 28.1 \\
\hline Communication with Colleagues and Other Health Care Professionals & 18 & 28.1 \\
\hline Communication with Child, Adolescent, Elder and Disabled Patients & 15 & 23.4 \\
\hline Communication Handicaps/Lack of Communication and its Reasons & 13 & 20.3 \\
\hline Interpersonal, Intergroup, Organizational, and Mass Communication & 9 & 14.1 \\
\hline Conflicts and their Solutions & 6 & 9.4 \\
\hline Communication Mistakes & 4 & 6.2 \\
\hline Cultural Differences in Communication & 3 & 4.7 \\
\hline Convincing Communication & 2 & 3.1 \\
\hline $\begin{array}{l}\text { Communication in Particular Situations (Disasters, Epidemics, } \\
\text { Accidents, etc.) }\end{array}$ & 1 & 1.6 \\
\hline Reputation Management & 1 & 1.6 \\
\hline Crisis Management & 1 & 1.6 \\
\hline Media Relations for Doctors & 1 & 1.6 \\
\hline
\end{tabular}


In forming the table, the fact that some faculties include more than one theoretical communication education topic in their curriculums has been considered. It could be said the theoretical communication education in the medical faculties primarily focuses on the communication between doctors and their patients, and is aimed at teaching doctors communication skills in line with this purpose. It is also noteworthy that other topic titles focused on in the theoretical communication (education) are related to effective and productive management of health communication with respect to interpersonal communications in general.

\section{DISCUSSION AND CONCLUSION}

Health communication is a discipline that has the aim of raising awareness about diseases and preventive measures individually and socially, encompassing strategies and practices that focus on protection, improvement and gaining back health. Health communication studies emphasize interpersonal communication process at the micro-level, and look at what sort of effect communication has on gaining health back, adopting ideal health behaviors and belief, doing a correct diagnosis and choosing the right way of treatment, making collaboration between doctors and patients during treatment, effective and productive use of time, and bringing out patient satisfaction. The macro-level of health communication is interested in creating awareness and improving public consciousness about health risks, and offering target audience with knowledge about health as well as designing and carrying out health communication campaigns through mass communication tools.

In spite of the widening scope of health communication, the micro-level of the discipline with the traditional point of view has more importance and communication between health care providers and patients stands out as a topic of research (Dutta, 2009; Hamel, 2010). A successful management of health communication contributes to reaching desired health results such as making a correct diagnosis and carrying out a right way of treatment, increasing the degree of patient satisfaction, and the emergence of patient-doctor collaboration. As providing health care service is based on interpersonal communications, it necessary for the people who are health care providers, particularly doctors, to be equipped with communication education that assists them to gain necessary communication skills in addition to their medical education (Schiavo, 2007; Bachman et al., 2013; Street \& Haes, 2013; Deveugele, 2015; Solmaz \& Duğan, 2018). Nowadays, in line with this agreement in the literature and the necessity of communication education in medicine, courses that are aimed at gaining and improving communication skills are being added to the curriculums of programs that offer medical education (Akyurt, 2009; Kiessling et al., 2010; Campbell et al., 2013). Accordingly, a research has been designed to answer whether the curriculums of the faculties that provide medical education in Turkey has been constructed with a concern for communication education, and thus, the curriculums of 104 Turkish faculties that provide medical education at the undergraduate level have been investigated.

The findings obtained with the use of content analysis, a qualitative research method, have shown that the majority of the medical faculties offering undergraduate education in Turkey $(n=64,61.4 \%)$ has theoretical communication education in their curriculums. Such a result could be interpreted as evidence that the accepted norms in the literature have been observed by the related faculties in Turkey. In addition, it could be suggested the entire medical faculties include theoretical communication education in their curriculums.

When the distribution of theoretical education according to undergraduate years has been taken into consideration, it has been noticed that freshman year $(n=57,27.3 \%)$ is more concentrated on communication education, followed by the third $(n=32,15.3 \%)$, second $(n=27,12.9 \%)$ and fourth years $(n=3,1.4 \%)$. It should be remembered that the first three years of undergraduate medical education focus on theoretical education, and thus, the theoretical communication education is distributed in the curriculum of the first half of the education, described as pre-clinical period. It is known that at the internship level, named as clinical period, prospective do- 
ctors have the opportunity of communicating with patients and their acquaintances in practice. However, it is still important to meet the requirement of equipping the students with the theoretical knowledge aimed at acquiring and improving communication skills in their pre-clinical period.

As a result of the analysis aimed at learning whether theoretical communication education is offered as a separate course in the curriculums or as a topic integrated into other medical courses, it has been found out that out of the 64 medical schools, 51 (79.7\%) give communication education as theoretical courses and the remaining 13 (20.3\%) does not have any separate theoretical courses.

The number of faculties that integrate communication education into other courses is 27 (42.2\%). Since the communication education necessary for medical education requires a multidimensional and comprehensive education including various issues such as gaining basic communication skills, understanding verbal and nonverbal communication, learning how to communicate with others in difficult and bad situations, knowing how to communicate with different types of patients, e.g., child, adolescent, elder and disabled, and appreciating how to overcome cultural differences, it is suggested theoretical communication education is done within the first three years of medical education named as pre-clinical period and is taught in separate courses.

This study has dealt with the position of theoretical communication education in health care service by looking into the curriculums of Turkish medical faculties that provide undergraduate education. It offers insights for the next studies that will deal with the position of communication in the education of other health professionals who provide health care services, e.g., nurses, pharmacists and dentists, and that will focus on the current position of communication education in relation to health communication in other countries. 


\section{REFERENCES}

Bachmann, C., Abramovitch, H., Barbu, C. G., Cavaco, A. M., Elorza, R. D., Haak, R., ...Rosenbaum, M. (2013). A European Consensus on Learning Objectives for A Core Communication Curriculum in Health Care Professions. Patient Education and Counseling, 93, 18 - 26.

Başol, E. (2018). Hasta Ile Sağıık Çalışanları (Doktor ve Hemşire) Arasındaki Illetişim Sorunları ve Çözüm Önerileri. International Anatolia Academic Online Journal, 4(1), 1 - 18.

Berry, D. (2007). Health Communication Theory and Practice. England: Open University Press.

Campbell, S. H., Pagano, M. P., O’Shea, E. R., Connery, C. \& Caron, C. (2013). Development of the Health Communication Assessment Tool: Enhancing Relationships, Empowerment, And Power - Sharing Skills. Clinical Simulation in Nursing, 9, $543-550$.

Çınarlı, ì. (2008). Sağlık Iletişimi ve Medya. Ankara: Nobel Yayın Dağıtım.

Dalen, J. (2013). Communication Skills in Context: Trends and Perspectives. Patient Education and Counceling, 92, $292-295$.

Deveugele, M. (2015). Communication Training: Skills and Beyond. Patient Education and Counceling, 98, $1287-1291$.

Dutta, M. J. (2009). Health Communication: Trends and Future Directions. J. C. Parker \& E. Thorson (Eds.). In Health Communication in the New Media Landscape (59-92). New York: Springer Publishing Company.

Edgerton, E. (2009). Changing Health Behavior Through Games. R. E. Ferdig (Ed.), Handbook of Research On Effective Electronic Gaming In Education. (370 - 387). Hershey: IGI Global.

Hamel, P. C. (2010). The Meaning Of Health Communication: Maybe They Just Don't Know What They Don't Know?. Journal of Communication In Healthcare, 3(2), 98 - 112.

Higher Education Institute (YÖK). https://www.yok.gov.tr/universiteler/universitelerimiz, Access Date: 01.09.2019.

İrak, H., Taşçıoğlu, R., Dal, M. \& Tunç, Y. (2017). Sağlık Hizmetleri Meslek Yüksekokulu Öğrencilerinin İletişim Becerileri: Iğdır Üniversitesi Örneği. Atatürk Iletişim Dergisi, Special Issue, 187 - 202.

Kiessling, C., Dieterich, A., Fabry, G., Hölzer, H., Langewitz, W., Mühlinghouse, I., ... Schubert, S. (2010). Communication and Social Competencies in Medical Education In German - Speaking Countries: The Basel Consensus Statement Result Of A Delphi Survey. Patient Education and Counceling, 81, $259-266$.

Kreps, G. L. (2012). Health Communication Inquiry and Health Outcomes. Comunicação E Sociedade, Special Issue, $11-22$.

Kreps, G. L., Bonaguro, E. W. \& Query, J. L. (1998). The History and Development of the Field of Health Communication. L. D. Jackson \& B. K. Duffy (Eds.). In Health Communication Research: Guide to Developments and Directions. (Pp. 1 -15). Westport, CT: Greenwood Press. 
Kreps, G. L. \& Thornton, B. (1992). Health Communication: Theory and Practice. USA: Waveland Press.

Koçak, A. \& Bulduklu, Y. (2010). Sağlık Illetişimi: Yaşlıların Televizyonda Yayınlanan Sağlık Programlarını İzleme Motivasyonları. Selçuk iletişim Dergisi, 6(3), 5 - 17.

Mckeever, B. W. (2014). The Status of Health Communication: Education and Employment Outlook for A Growing Field. Journal of Health Communication, 19(12), 1408 - 1423.

Okay, A. (2012). Sağlık Iletişimi. İstanbul: Derin Yayınları.

Ratzan, S. C., Stearns, N. S., Payne, J. G., Amato, P. P., Liebergott, J. W. \& Madoff, M. A. (1994). Education for The Health Communication Professionals: A Collaborative Curricular Partnership. American Behavioral Scientist, 38(2), $361-380$.

Rosiek - Kryszewska, A., Leksowski, L. Rosiek, A., Leksowski, K. \& Goch, A. (2016). Clinical Communication in the Aspect of Development of New Technologies and E - Health in the Doctor - Patient Relationship. A. Rosiek \& K. Leksowski (Eds.). In Organizational Culture and Ethics in Modern Medicine. (pp. 18 - 51). Hershey: IGI Global.

Schiavo, R. (2007). Health Communication from Theory to Practice. San Francisco: John Wiley \& Sons.

Shin, K. R., Jung, D. \& Shin, S. J. (2011). Communication and Nursing Relationships. A. Cashin \& R. Cook (Eds.). In Evidence - Based Practice in Nursing Informatics: Concepts and Applications. (pp. 25 - 39). Hershey: IGI Global.

Solmaz, B. \& Duğan, Ö. (2018). Sağlık Çalışanı ile Hasta Yakınları Arasında Yaşanan Şiddetin Nedenlerinden İletişim Üzerine Bir İnceleme. AiвÜ Sosyal Bilimler Enstitüsü Dergisi, 18(2), 185 - 206.

Street, R. L. \& Haes H. C. J. M. (2013). Designing A Curriculum for Communication Skills Training from A Theory and Evidence - Based Perspective. Patient Education and Counseling, 93, 27 - 33.

Xie, J., Ding, S. Wang, C., \& Liu, A. (2013). An Evaluation of Nursing Students' Communication Ability During Practical Clinical Training. Nurse Education Today, 33, $823-827$.

Yılmaz, E. (2013). Türkiye'de Hastaların Internette Tıbbi Enformasyon Arama Davranışının Doktor - Hasta Illetişimine Etkileri. Galatasaray Iletişim Dergisi, Special Issue, 93 - 108. 